\title{
STUDI PENGELASAN TUNGSTEN INERT GAS TERHADAP KEKUATAN SAMBUNGAN DAN SIFAT MEKANIK PADA BAJA AISI 1045
}

\author{
Fajar Banjarnahor ${ }^{1}$, Alfian H.Siregar ${ }^{2}$, M. Sabri ${ }^{3}$, Indra $^{4}$, Mahadi $^{5}$ \\ 1,2,3,4,5 Departemen Teknik Mesin, Fakultas Teknik, Universitas Sumatera Utara \\ Email: fajar.banjarnahor@gmail.com
}

\begin{abstract}
One of the metal joining technology with welding method is TIG (Tungsten Inert Gas) or GTAW (Gas Tungsten Arch Welding). With TIG welding we can connect metals such as: Aluminum, Copper, Carbon Steel, and Stainless Steel. This study was conducted to determine the effect of TIG welding on mechanical properties, microstructure, and strength of welded joints on AISI 1045 Steel. Welding is done using AWS EWTh2 tungsten and with ER70S-G filler, 8 bar L / m flow rate, $100 \mathrm{~A}$ current strength, with $\mathrm{V}$ joint connection. The test methods carried out were hardness test with Brinell Hardness Tester method, tensile test with Tensile Tester, microstructure test with Metallurgycal Microscope, and simulation of welded joints with Solidworks software. The average results from the hardness test were obtained 227.6442269 BHN for welded specimens, 198.2885114 BHN for testing in the HAZ region, and 177.8677098 BHN for testing at the weld point. The results of the tensile test without welding, the average stress is $725.849257 \mathrm{~N} / \mathrm{mm} 2$, strain $20 \%$, modulus of elasticity 3828.4847 $\mathrm{N} / \mathrm{mm} 2$. And for weld specimens, the average stress is $709.925687 \mathrm{~N} / \mathrm{mm} 2$, Strain $11.33 \%$, and the modulus of elasticity is $6309.7133 \mathrm{~N} / \mathrm{mm} 2$. The results of microstructure testing showed that welded specimens had a ferrite microstructure, a weld point with cementite microstructure, and a HAZ area with a larger size ferrite microstructure. The strength of weld joint with simulation in Soidworks, we get the connection strength is $1090 \mathrm{MPa}$ with a tensile load of $40000 \mathrm{~N}$.
\end{abstract}

Keywords: TIG Welding, AISI 1045 Steel, Mechanical Property, Weld Strength

\section{Abstrak}

Salah satu teknik penyambungan logam dengan cara pengelasan adalah dengan pengelasan TIG(Tungsten Inert gas) atau GTAW (Gas Tungsten Arch Welding). Dengan las TIG kita dapat menyambung logam seperti: Aluminium, Tembaga, Carbon Steel, dan Stainless Steel. Penelitian ini dilakukan untuk mengetahui pengaruh pengelasan TIG terhadap sifat mekanik, struktur mikro, dan kekuatan sambungan las pada Baja AISI 1045. Pengelasan dilakukan dengan menggunakan tungsten AWS EWTh2 dan dengan filler ER70S-G, laju aliran 8 bar L/m, kekuatan arus 100 A, dengan sambungan kampuh V. Metode pengujian yang dilakukan adalah uji kekerasan dengan metode Brinell Hardness Tester, uji tarik dengan Tensile Tester, uji struktur mikro dengan Metallurgycal Microscope, dan simulasi sambungan las dengan software Solidworks. Hasil rata-rata dari uji kekerasan didapat 
227.6442269 BHN untuk spesimen tanpa las, 198.2885114 BHN untuk pengujian di daerah HAZ, dan 177.8677098 BHN untuk pengujian di titik las. Untuk hasil uji tarik tanpa las didapat rata-rata tegangan $725.849257 \mathrm{~N} / \mathrm{mm}^{2}$, regangan $20 \%$, modulus elastisitas $3828.4847 \mathrm{~N} / \mathrm{mm}^{2}$. Dan untuk spesimen las didapat rata- rata tegangan 709,925687 N/mm², Regangan $11.33 \%$, dan modulus elastisitas 6309.7133 $\mathrm{N} / \mathrm{mm}^{2}$. Hasil pengujian struktur mikro didapat bahwa spesmen tanpa las memiliki struktur mikro ferrite, daerah las dengan struktur mikro cementite, dan daerah HAZ dengan mikrostruktur ferrite dengan ukuran yang lebih besar. Untuk kekuatan sambungan dengan simulasi di Soidworks didapat kekuatam sambungan adalah $1090 \mathrm{MPa}$ denga beban tarik $40000 \mathrm{~N}$.

Kata kunci: Las TIG, Baja AISI 1045, Sifat Mekanik, Kekuatan Sambungan Las 


\section{Pendahuluan}

Saat ini teknik penyambungan logam di bidang pengelasan sudah berkembang pesat. Pada konstruksi yang menggunakan bahan baku logam, hampir sebagian besar sambungannya dikerjakan dengan cara pengelasan. Salah satunya adalah Gas Tungsten Arc Welding (GTAW) atau biasa yang disebut Tungsten Inert Gas (TIG).

Tungsten Inert Gas ( TIG) welding adalah proses pengelasan busur yang menggunakan elektroda tungsten yang digunakan tidak untuk menghasilkan lasan. Pengelasan TIG adalah proses penyambungan material ferrous atau non ferrous dengan memanaskan sampai suhu pengelasan, dengan atau tanpa menggunakan logam pengisi ( filler metal) $^{[1]}$.

Pengelasan baja menggunakan las TIG dengan pelindung gas mulia (Argon) diharapkan dapat memberikan hasil sambungan las yang bagus, baik secara fisis maupun mekanis. Sifat mekanis tersebut salah satunya adalah kekuatan tarikan yang akan mempengaruhi kekuatan sambungan. Faktor yang memungkinkan mempengaruhi penurunan sifat mekanis sambungan las TIG antara lain adalah ketidak sesuaian dalam pemilihan kawat las (filler metal ) dan kesalahan dalam penentuan parameter las $\mathrm{TIG}^{[2]}$. Las TIG dapat digunakan dalam pengelasan Aluminium, Stainless stell, Baja paduan, dan logam lainnya.

Salah satu material yang banyak dipakai dalam pengelasan adalah baja AISI 1045. Baja AISI 1045 adalah baja karbon dengan paduan karbon 0,45\% tanpa tambahan sulfur dan fosfor. Baja spesifikasi ini banyak digunakan sebagai komponen automotif misalnya untuk komponen roda gigi pada kendaraan bermotor. Oleh karena itu penulis ingin mengetahui kekuatan sambungan las dan sifat mekanik Baja AISI 1045 dengan las TIG dengan melakukan penelitian dan beberapa pengujian, seperti tensile test, hardness test, pengujian struktur mikro, dan simulasi uji kekuatan sambungan di SOLIDWORKS. Kemudian hasil analisa akan dibandingkan dengan spesimen tanpa dilas dengan pengujian yang sama.

\section{Metode}

Proses pengelasan dilakukan di Bengkel Team Horas USU dan pengujian dilakukan di Lab. Fenomena Dasar dan Lab. Ilmu logam Fisik Departemen Teknik Mesin, Fakultas Teknik, Universitas Sumatera Utara. Bahan yang digunakan adalah Baja AISI 1045 dengan titik lebur 1401-1539 ${ }^{\circ} \mathrm{C}$, kekuatan tarik 565-700 MPa, dan komposisi kimia pada Tabel 2.1.

Tabel 2.1. Komposisi Kimia Baja AISI 1045[3]

\begin{tabular}{|l|c|l|l|l|l|}
\hline Element & $\begin{array}{c}\text { Carbon } \\
(\mathrm{C})\end{array}$ & Magnesium $(\mathrm{Mg})$ & Sulfur (S) & Phosphorous (P) & Iron (Fe) \\
\hline Content $(\%)$ & $0.43-$ & $0.60-0.90$ & $0.05($ Max $)$ & $0.04($ Max $)$ & Balance \\
& 0.50 & & & \\
\hline
\end{tabular}


Baja AISI 1045 dilas dengan TIG(Tungsten Inert Gas) dengan filler ER70S-G, dan kuat arus 100 Ampere. Spesimen uji kekerasan menggunakan standarisasi ASTM E 10 dengan dimensi pada Gambar 2.1a dibawah, spesimen ini juga nanti yang akan dilanjutkan
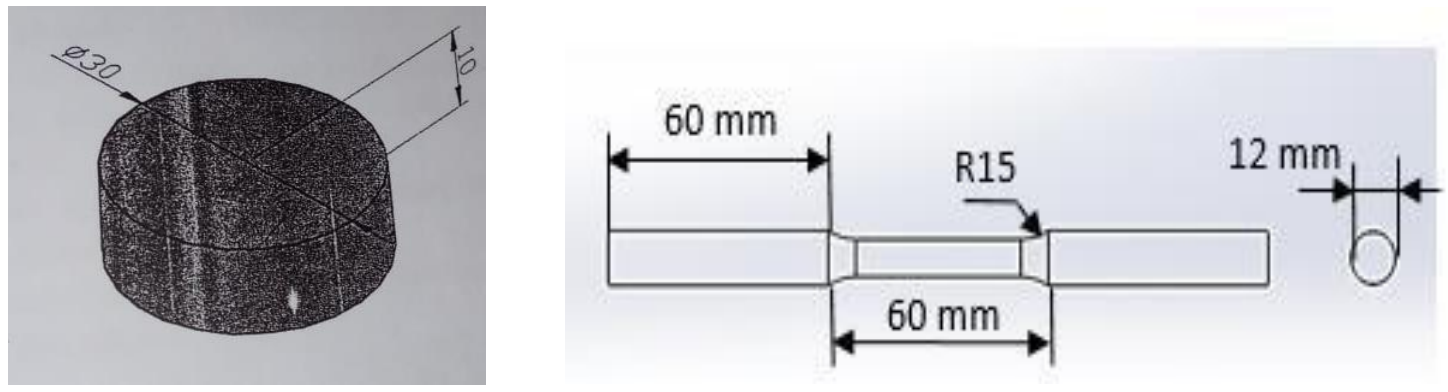

untuk uji struktur mikro. Untuk spesimen uji tarik menggunakan standarisasi ASTM E8 dengan dimensi pada Gambar. 2.1b.

(a)

(b)

Gambar 2.1. Spesimen uji kekerasan ASTM E10 (a), Spesimen Uji Tarik ASTM E8(b) ${ }^{[3]}$.

Untuk pemodelan simulasi kekuatan sambungan las dengan Solidworks dibuat seperti Gambar 2.2, dimana panjang total spesimen $200 \mathrm{~mm}$. Bentuk balok $110 \mathrm{~mm}$ x $50 \mathrm{mmx} 50$ $\mathrm{mm}$, dan untuk objek uji yaitu $60 \mathrm{~mm}$ diameter $12 \mathrm{~mm}$ dan $30 \mathrm{~mm}$ untuk diameter $8 \mathrm{~mm}$. Dengan asumsi pengelasan sempurna standarisasi Amerika, dan dengan filler ER70S-G.

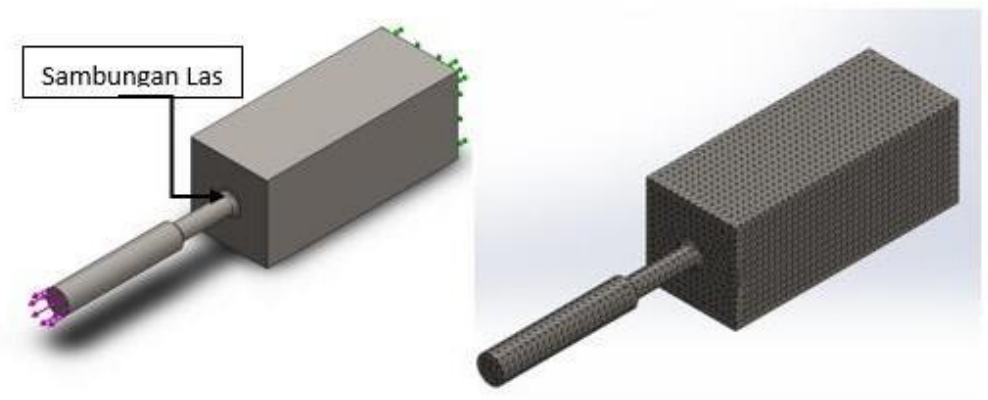

Gambar 2.2. Pemodelan dan Meshing Spesimen Uji di Solid Work

2.1 Metode Numerik

1. Nilai kekerasan. ${ }^{[4]}$

Pengujian kekerasan dilakukan dengan metode Brinell, dengan persamaan :

$$
B H N=
$$


$D \stackrel{\sqrt{ }}{-} d^{22}$

Dimana : $\mathrm{P}=$ beban yang diberikan $(1500 \mathrm{~kg}), \mathrm{D}=$ diameter bola indentor $(10 \mathrm{~mm}), \mathrm{d}=$ diameter indentasi $(\mathrm{mm})$

2. Uji kekerasan ${ }^{[5]}$

- Tegangan (Stress)

$\alpha=P$ 
Dimana $: \sigma=$ tegangan $\left(\mathrm{N} / \mathrm{mm}^{2}\right), \mathrm{P}=\operatorname{Beban} \operatorname{Maksimum}(\mathrm{N}), \mathrm{A}=$ luas penampang $\left(\mathrm{mm}^{2}\right)$.

- Regangan (Strain)

$$
e=\frac{\Delta L}{L o} \times 100 \%
$$

Dimana: $\mathrm{e}=$ regangan $(\%), \Delta \mathrm{L}=$ Perpanjangan $\left(\mathrm{mm}^{2}\right), \mathrm{Lo}=$ Panjang Awal $(\mathrm{mm})$.

- Modulus Elastisitas

$$
E={ }_{e}^{\sigma}
$$

Dimana: $\mathrm{E}=$ Modulus elastisitas $\left(\mathrm{N} / \mathrm{mm}^{2}\right), \sigma=$ Tegangan $(\mathrm{N} / \mathrm{mm} 2), \mathrm{e}=$ Regangan $(\%)$

\subsection{Flow Chart}

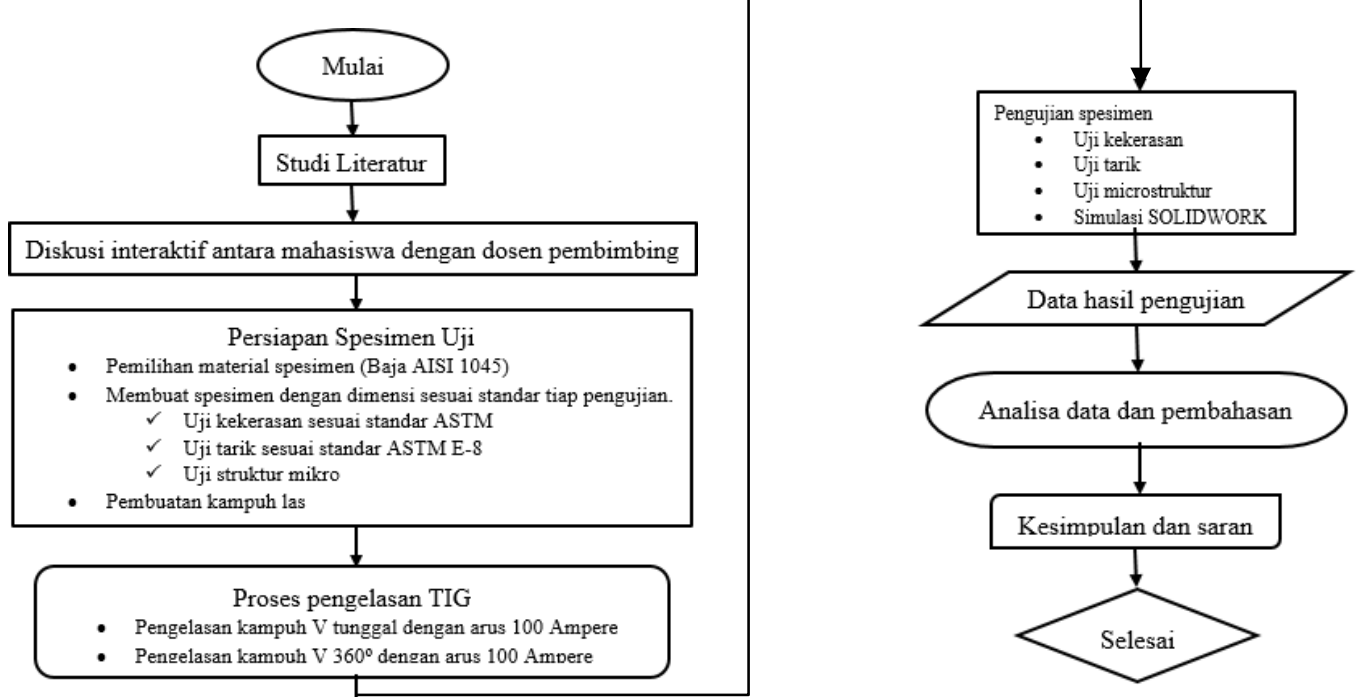

Gambar 2.3. Flow Chart

\section{Analisis dan Pembahasan}

\subsection{Uji Kekerasan}

Tujuan pengujian kekerasan dalam penelitian ini adalah untuk mengetahui perubahan nilai kekerasan Baja AISI 1045 sebelum dan sesudah pengelasan, yakni pada daerah HAZ dan pada kampuh yang sudah diisi logam pengisi. Penghitungan nilai kekerasan dari benda uji yang dilakukan dalam penelitian ini adalah dengan menggunakan skala Brinell yang bekas injakannya atau indentasinya dapat dilihat dengan teropong Indentor dan nilai kekerasannyanya dikonversikan dengan rumus BHN.

Tabel 3.1. Hasil Pengujian Kekerasan Metode Brinell

\begin{tabular}{|c|c|c|c|c|c|}
\hline \multirow{3}{*}{ No } & \multirow{3}{*}{ Daerah Test } & \multicolumn{3}{|c|}{ Titik } & \multirow{2}{*}{ Rata - rata } \\
\cline { 3 - 5 } & & Titik & Titik & Titik & \\
\hline 1 & Tanpa dilas & 2.9 & 2.8 & 2.9 & 2.86 \\
\hline
\end{tabular}




\begin{tabular}{|c|c|c|c|c|c|}
\hline 2 & Titik las & 3.3 & 3.2 & 3.2 & 3.23 \\
\hline 3 & $\begin{array}{c}\text { Daerah } \\
\text { HAZ }\end{array}$ & 3.0 & 3.1 & 3.1 & 3.06 \\
\hline
\end{tabular}


Tabel 3.2. Nilai Kekerasan Tiap Daerah Uji Dalam BHN

\begin{tabular}{|c|c|c|c|}
\hline Daerah Tes & $\begin{array}{c}\text { Titik } \\
\text { Uji }\end{array}$ & $\begin{array}{l}\text { Nilai } \\
\text { d(mm) }\end{array}$ & $\begin{array}{c}\text { Nilai } \\
\text { Kekerasan(BHN) }\end{array}$ \\
\hline \multirow{4}{*}{ Tanpa las } & $\mathrm{i}$ & 2.9 & 222.3270726 \\
\hline & ii & 2.8 & 238.8535032 \\
\hline & iii & 2.9 & 222.3270726 \\
\hline & $\begin{array}{c}\text { Rata- } \\
\text { rata }\end{array}$ & $\begin{array}{c}2.86666666 \\
7 \\
\end{array}$ & 227.6442269 \\
\hline \multirow{4}{*}{ Daerah HAZ } & $\mathrm{i}$ & 3.1 & 193.9397546 \\
\hline & ii & 3.0 & 207.4245437 \\
\hline & iii & 3.1 & 193.9397546 \\
\hline & $\begin{array}{c}\text { Rata- } \\
\text { rata }\end{array}$ & $\begin{array}{c}3.06666666 \\
7\end{array}$ & 198.2885114 \\
\hline \multirow{4}{*}{ Titik las } & $\mathrm{i}$ & 3.3 & 170.5515724 \\
\hline & ii & 3.2 & 181.6982431 \\
\hline & iii & 3.2 & 181.6982431 \\
\hline & $\begin{array}{c}\text { Rata- } \\
\text { rata }\end{array}$ & $\begin{array}{c}3.23333333 \\
3\end{array}$ & 177.8677098 \\
\hline
\end{tabular}

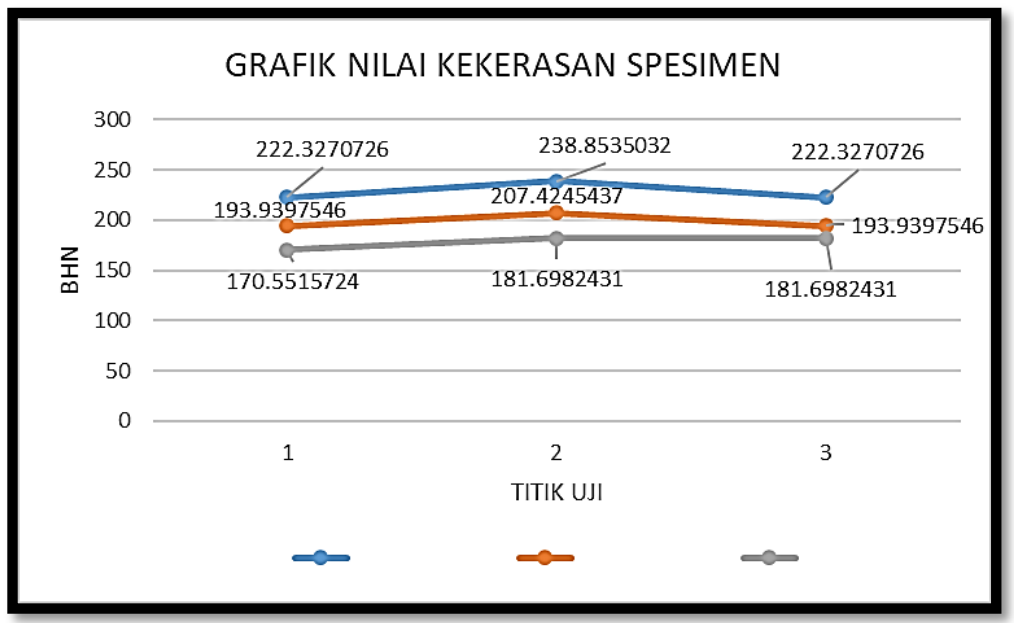

Gambar 3.1. Grafik Nilai Kekerasan Spesimen Dalam Satuan BHN

\subsection{Uji Tarik}

Berdasarkan hasil pengujian tarik Baja AISI 1045 yang telah mengalami proses pengelasan TIG dengan kuat arus pengelasan 100 A. Pada saat pengujian spesimen mengalami patahan didaerah HAZ. Untuk angka kekuatan tarik Baja AISI 1045 yang dapat dilihat pada tabel di bawah ini.

Tabel 3.3. Hasil Uji Tarik

\begin{tabular}{|c|c|c|c|c|c|c|c|c|c|}
\hline NO & $\begin{array}{c}\text { Do }(\mathrm{mm} \\
)\end{array}$ & $\begin{array}{c}\text { Lo(mm } \\
)\end{array}$ & $\begin{array}{c}\text { Ao(mm } \\
)\end{array}$ & Fs (N) & $\begin{array}{c}\text { Ff } \\
(\mathrm{N})\end{array}$ & $\begin{array}{c}\text { Fmax } \\
(\mathrm{N})\end{array}$ & $\begin{array}{c}\text { D1 }(\mathrm{mm} \\
)\end{array}$ & $\begin{array}{c}\text { A1 }\left(\mathrm{mm}^{2}\right. \\
)\end{array}$ & $\begin{array}{c}\text { L1 } \\
(\mathrm{mm})\end{array}$ \\
\hline I & 8 & 50 & 50.24 & 20000 & $\begin{array}{c}2950 \\
0\end{array}$ & 36300 & 5 & 19.625 & 62 \\
\hline
\end{tabular}




\begin{tabular}{|c|c|c|c|c|c|c|c|c|c|}
\hline II & 8 & 50 & 50.24 & 21000 & $\begin{array}{c}2900 \\
0\end{array}$ & 36000 & 5 & 19.625 & 57 \\
\hline III & 8 & 50 & 50.24 & 21000 & $\begin{array}{c}3000 \\
0\end{array}$ & 37100 & 5 & 19.625 & 61 \\
\hline IV & 8 & 50 & 50.24 & 20000 & $\begin{array}{c}2900 \\
0\end{array}$ & 35500 & 5 & 19.625 & 56 \\
\hline V & 8 & 50 & 50.24 & 20000 & $\begin{array}{c}3000 \\
0\end{array}$ & 35600 & 6 & 28.26 & 55 \\
\hline VI & 8 & 50 & 50.24 & 19000 & $\begin{array}{c}2980 \\
0\end{array}$ & 35900 & 5 & 19.625 & 56 \\
\hline
\end{tabular}

Ket : I, II, dan III : spesimen yang tanpa dilas. Dan IV,V, dan VI : spesimen yang dilas. 


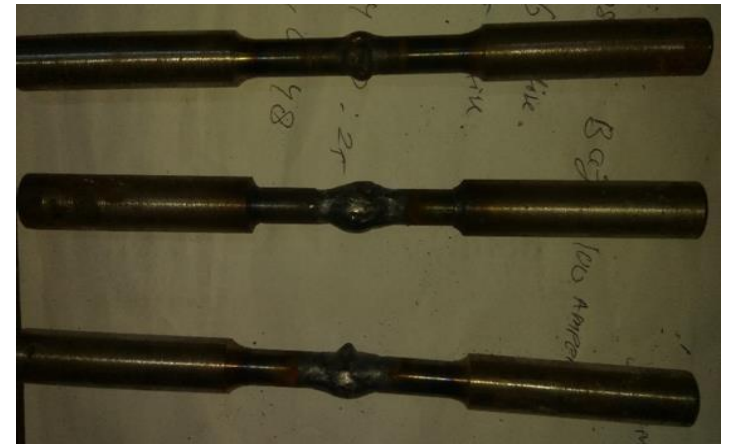

(a)

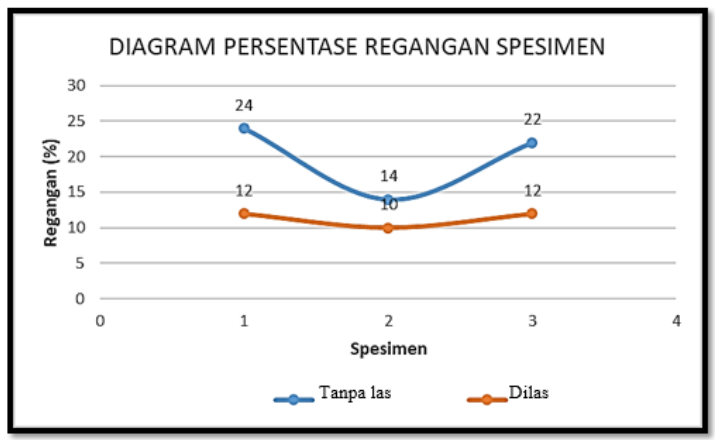

(c)

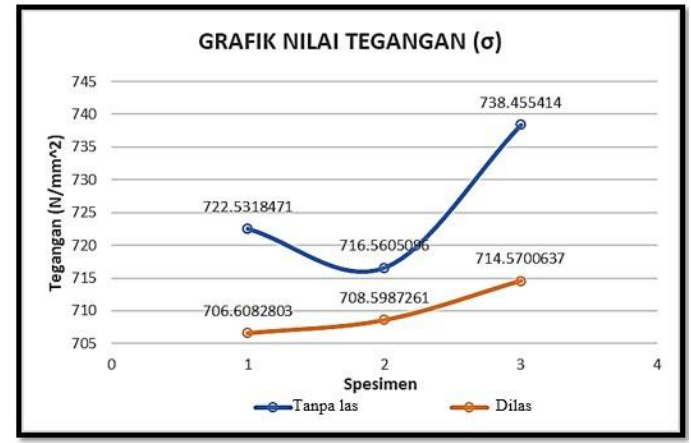

(b)

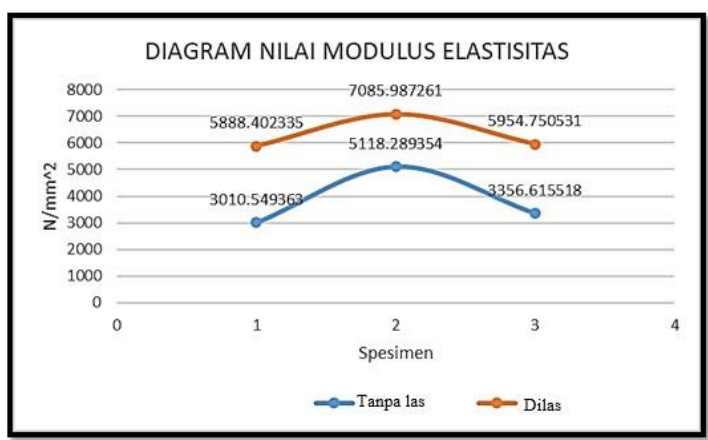

(d)

Gambar 3.2. Spesimen Uji Tarik Setelah Dilas (a), Diagram Tegangan Rata-rata (b), Diagram Regangan Rata- rata (c), Diagran Modulus Elastisitas Rata-rata (d).

\subsection{Uji Struktur Mikro}

Pengujian mikrostruktur dilakukan dengan menggunakan "Reflected Metallurgical Microscope" dengan type Rax Vision No.545491, MM -10A,230V-50Hz. Pengujian mikrostruktur ini dilakukan pada spesimen Baja AISI 1045 yang telah dilakukan pengelasan TIG dengan kuat arus $100 \mathrm{~A}$.

Hasil foto mikro seperti diperlihatkan pada gambar-gambar berikut:
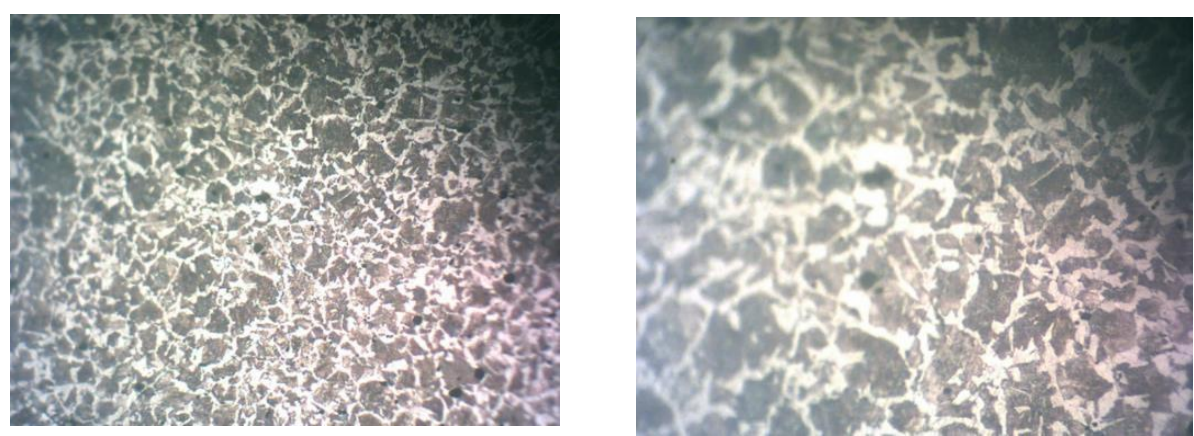

Gambar 3.3. Foto Struktur Mikro Tanpa Dilas $100 \& 200$ x Perbesaran 
Gambar 3.3 menunjukkan struktur mikro Baja AISI 1045 sebelum dilas. Pada gambar terlihat bahwa baja ini memiliki struktur mikro Ferrite. 

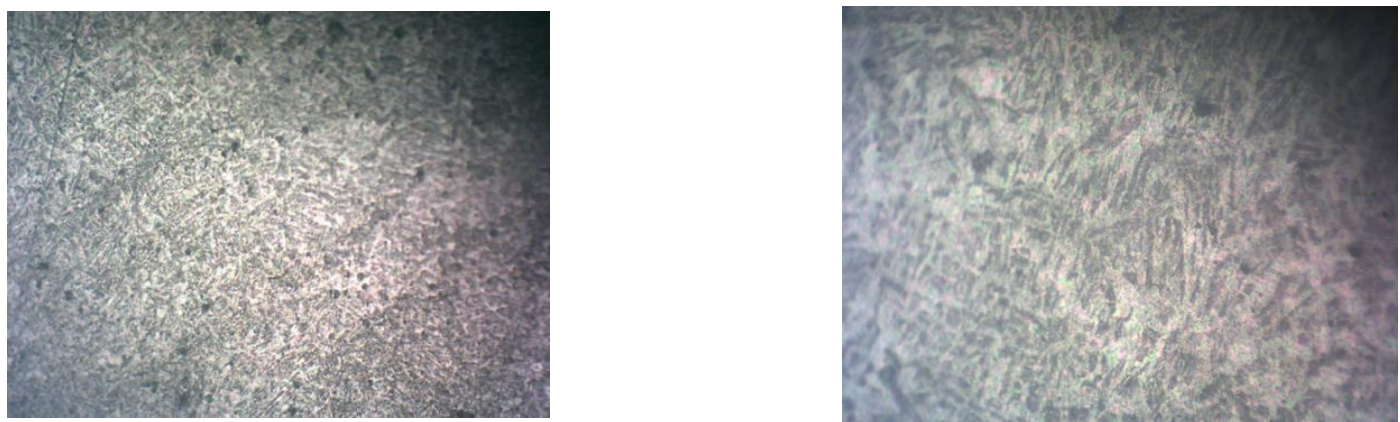

Gambar 3.4. Foto Struktur Mikro Titik Las(Filler) $100 \& 200$ x Perbesaran

Pada gambar 3.4 dapat diketahui bahwa daerah las dengan logam pengisi ER70S-G memiliki struktur mikro Cementite.
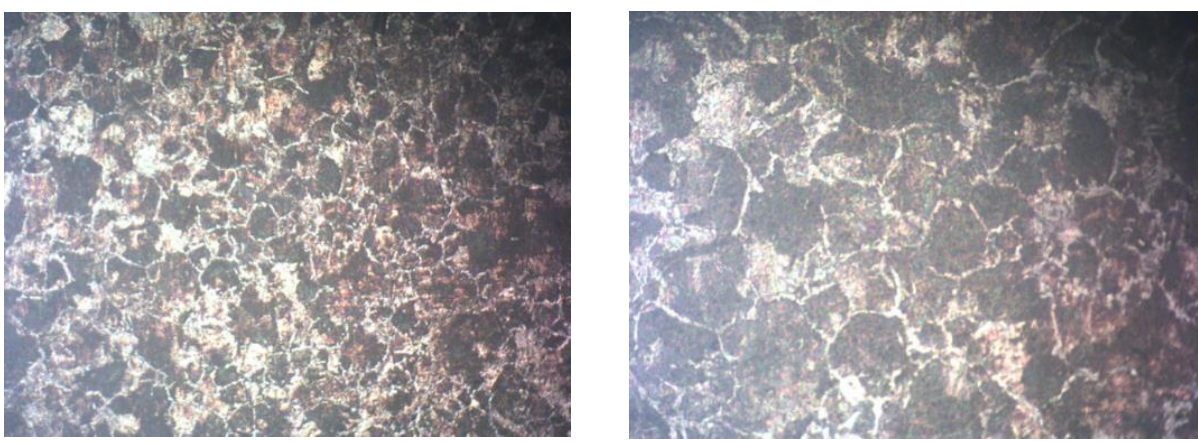

Gambar 3.5. Foto Struktur Mikro Daerah HAZ 100 \& 200 x Perbesaran

Struktur mikro pada daaerah HAZ memiliki struktur mikro yang sama dengan spesimen yang belum dilas, yakni struktur mikro Ferrite. Namun pada derah HAZ terjadi pergeseran struktur mikro yang menyebabkan berkurangnya kekerasan material.

\subsection{Simulasi SOLIDWORKS.}

Hasil simulasi dengan software SW menunjukkan nilai tegangan maksimum terjadi pada sambungan las yang menyebabkan spesinen menjadi putus adalah $1090 \mathrm{MPa}$ untuk beban tarik $40000 \mathrm{~N}$.

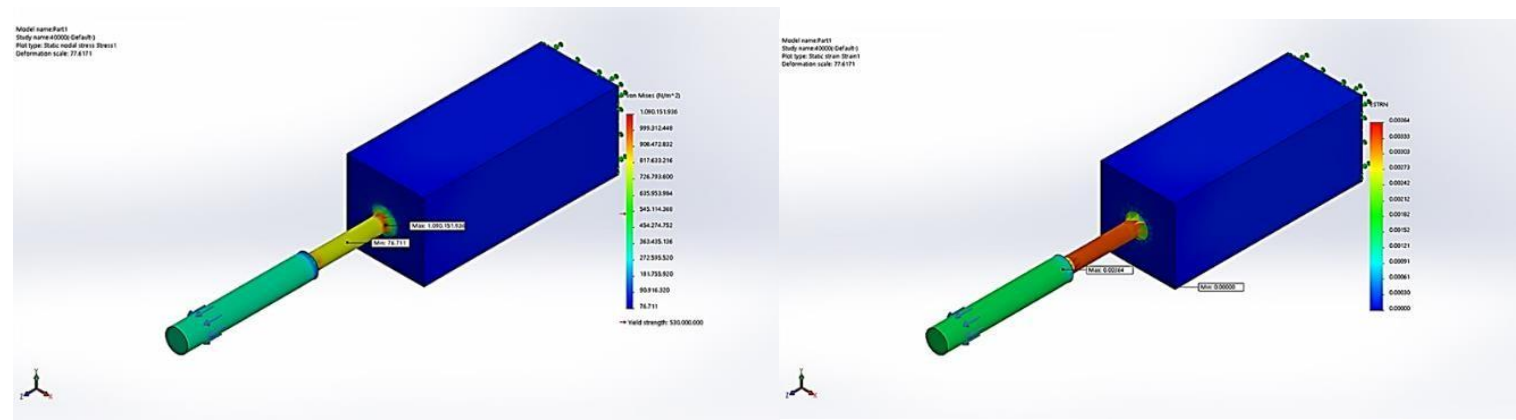

Gambar 3.6. Analisa Von Mises Stress dan Analisa Equivalen Strain 


\section{Kesimpulan}

1. Sifat mekanik baja AISI 1045 sebelum dan setelah pengelasan TIG adalah: nilai kekerasan sebelum pengelasan sebesar 227.6442269 BHN, pada daerah HAZ sebesar 198.2885114 BHN, pada titik las sebesar 177.8677098 BHN. Dan untuk kekuatan tarik tegangan rata-rata spesimen tanpa lasan sebesar 725,849257 N/mm², regangan rata-rata sebesar 20\%, dan nilai Modulus Elastisitasnya sebesar 3828,4847 N/mm², sedangkan pada spesimen yang dilas memiliki nilai tegangan rata-rata 709,925687 $\mathrm{N} / \mathrm{mm}^{2}$, dengan regangan rata-rata sebesar $11,33 \%$, dan nilai Modulus Elastisitasnya sebesar $6309,71333 \mathrm{~N} / \mathrm{mm}^{2}$. Dan pada saat uji tarik posisi patahan terjadi pada daerah HAZ (Heat Affective Zone).

2. Bentuk struktur mikro pada baja AISI 1045 sebelum pengelasan TIG adalah struktur mikro Feritte, pada titik las (filler) adalah cementite, dan pada daerah HAZ (Heat Affective Zone) memiliki struktur mikro yang sama dengan sebelum dilas yakni cementite, namun dengan ukuran yang berbeda. Struktur mikro cementite pada daerah HAZ sudah mengalami perubahan (mengembang), inilah yang menyebabkan melemahnya sifat mekanik material baja setelah pengelasan. Perubahan struktur mikro tersebut dipengaruhi oleh suhu pengelasan dan juga media pendingin.

3. Dengan simulasi menggunakan Software Solid Work, dengan pemodelan dan set up yang diaplikasikan, nilai tegangan maksimum terjadi pada sambungan las yang menyebabkan spesinen menjadi putus adalah $1090 \mathrm{MPa}$ untuk beban tarik $40000 \mathrm{~N}$.

\section{Referensi}

[1] Alip, M, 1989. Teoridan Praktik Las. Jakarta: Departemen Pendidikan dan kebudayaan

[2] Harsono Wiryosumatro \& Thosie Okumura, Teknologi Pengelasan Logam. Pradnya Paramita, Jakarta Cetakan ke IX

[3] https://www.azom.com/article.aspx?ArticleID=9153

[4] Groover, Mikell P. 1996. Fundamental Of Modern Manufacturing,Material, Proses And System.Penerbit Prentice-Hall Inc. USA

[5] Hendi Saputra, 2014. Analisis pengaruh media pendingin terhadap kekuatan tarik baja st37 pasca pengelasan menggunakan las listrik. Jurnal Ilmiah, Universitas Lambung Mangkurat. Kalimantan Selatan 